\title{
Lower Turonian record of belemnite Praeactinocamax from NW Siberia and its palaeogeographic significance
}

Martin Košták and Frank Wiese

Acta Palaeontologica Polonica 53 (4), 2008: 669-678 doi:http://dx.doi.org/10.4202/app.2008.0411

Specimens of the belemnitellid Praeactinocamax Naidin, 1964 are described from the Upper Cretaceous of NW Siberia

(Taimyr Region, Lower Agapa River, Russia). The rostra determined as Praeactinocamax

aff. plenus consist of an

aragonitic anterior part and a calcitic posterior part with a sharp boundary in between.

This boundary surface is referred to as the "alveolar fracture", and it is a typical

morphological feature of early belemnitellids and not a result of diagenetic processes.

The occurrence of Praeactinocamax in Arctic areas shows a wider

palaeobiogeographical distribution of the genus in the Late Cenomanian-Early

Turonian interval than previously known. This finding suggests that migration of the

late Cenomanian-early Turonian fauna occurred across Turgai channel. The

geographic position of these new records may also explain the occurrence of Praeactinocamax in the

Turonian of the US Western Interior Seaway, the origin of which has been hitherto unclear.

Key words: Belemnitellidae, Praeactinocamax, palaeobiogeography, Cenomanian, Turonian, Upper Cretaceous, Northern Siberia, Russia

Martin Košták [kostak@natur.cuni.cz], Ústav geologie a paleontologie,

Přírodovědecká fakulta UK, Praha 2, Alberov 6, 12843, Czech Republic; Frank Wiese

[frwiese@snafu.de] Fachrichtung Paläontologie, FU Berlin, Malteserstr. 74-100, D-12249 Berlin,

Germany.

This is an open-access article distributed under the terms of the Creative Commons

Attribution License (for details please see creativecommons.org), which permits unrestricted use, distribution, and reproduction in any medium, provided the original author and source are credited. 
PoF Full text (972.9 kB) 